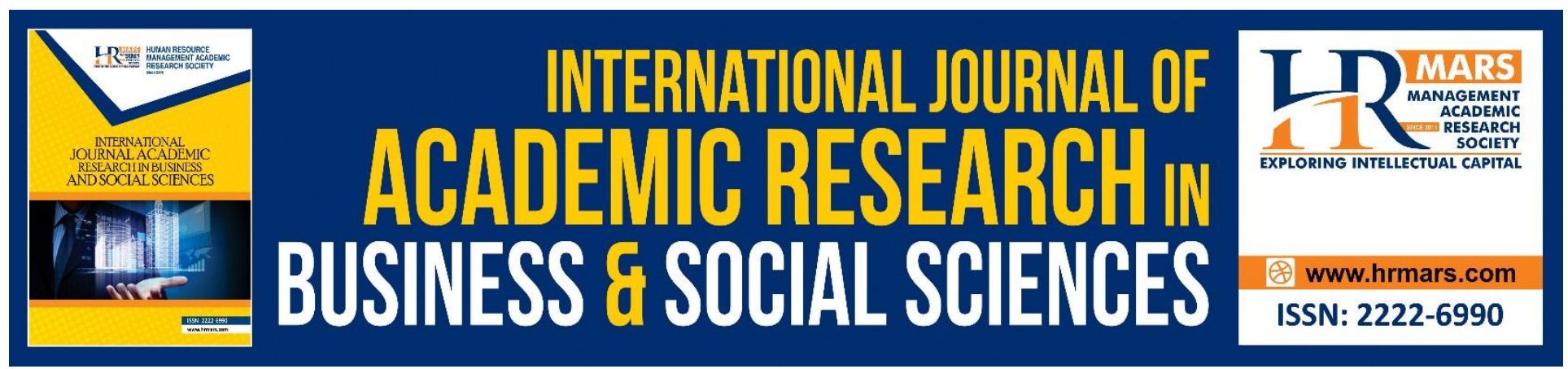

\title{
Correlations and Return Spillovers between Oil and the Oslo Tanker Firms
}

\begin{abstract}
Adeel Riaz, Ouyang Hongbing, Md Reza Sultanuzzaman, Shujahat Haider Hashmi
\end{abstract}

To Link this Article: http://dx.doi.org/10.6007/IJARBSS/v9-i1/5427

DOI: $\quad 10.6007 /$ IJARBSS/v9-i1/5427

Received: 23 Dec 2018, Revised: 19 Jan 2019, Accepted: 04 Feb 2019

Published Online: 13 Feb 2019

In-Text Citation: (Riaz, Hongbing, Sultanuzzaman, \& Hashmi, 2019)

To Cite this Article: Riaz, A., Hongbing, O., Sultanuzzaman, M. R., \& Hashmi, S. H. (2019). Correlations and Return Spillovers between Oil and the Oslo Tanker Firms. International Journal of Academic Research in Business and Social Sciences, 9(1), 526-536.

Copyright: (C) 2019 The Author(s)

Published by Human Resource Management Academic Research Society (www.hrmars.com)

This article is published under the Creative Commons Attribution (CC BY 4.0) license. Anyone may reproduce, distribute, translate and create derivative works of this article (for both commercial and non-commercial purposes), subject to full attribution to the original publication and authors. The full terms of this license may be seen

at: $\underline{\text { http://creativecommons.org/licences/by/4.0/legalcode }}$

\section{Vol. 9, No. 1, 2019, Pg. 526 - 536}

Full Terms \& Conditions of access and use can be found at http://hrmars.com/index.php/pages/detail/publication-ethics 


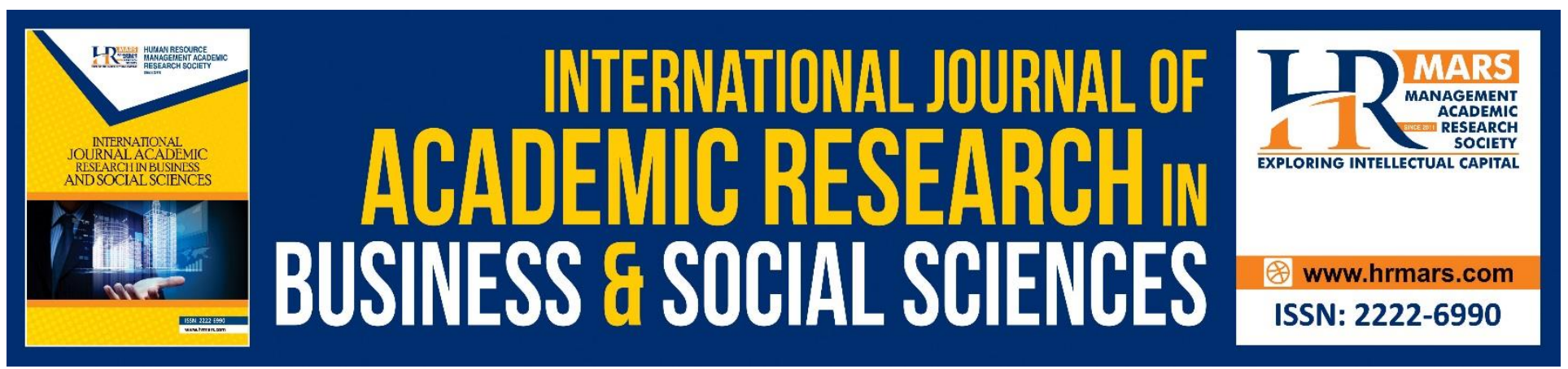

\title{
Correlations and Return Spillovers between Oil and the Oslo Tanker Firms
}

\author{
Adeel Riaz¹, Ouyang Hongbing, Md Reza Sultanuzzaman, Shujahat \\ Haider Hashmi \\ School of Economics, Huazhong University of Science and Technology, Wuhan, P.R. China \\ Corresponding author: ${ }^{1}$ riazadeel46@yahoo.com
}

\begin{abstract}
With the increased globalization the stock markets are integrated more than ever. Increased correlations among assets at global level have severe implications for the economies and industries specifically after the 2008 financial crisis. Following the crisis, another surge in oil price coupled with lower global demand has severely hit marine shipping industry. Therefore, we investigate the return spillovers from oil to the biggest tanker shipping companies of the world i.e. Frontline and Stolt Nielsen listed at Oslo Stock Exchange. We employed VAR DCC-GARCH and found a higher correlation among tanker companies than with the oil. Not surprisingly, the return spillovers from oil increased manifold soon after the financial crisis. The same increased level of correlation was observed for the tanker firms also following crisis period.
\end{abstract}

Keywords: VAR DCC-GARCH, Return spillovers, Marine shipping, Tanker, Frontline, Stolt Nielsen, Financial crisis, Oil prices

\section{Introduction}

Shipping is one of the oldest industries in the world. It had been a major source of transportation for centuries. Transportation is one such industry which relies heavily on oil as input. As shipping industries developed risks associated with shipping industry also changed. Norwegian shipping history goes as back as Vikings. It has the third largest fleet in the world in the shipping industry. Apart from being oil exporting country, fishing and shipping had been the two biggest industries for Norway. Since Norway is also an oil exporting country it required shipping to transport oil to other countries. Fisheries is an important part of Norwegian economy and it also increased its need of developing its shipping industry.

Fuel makes up about $50 \%$ of a ship's voyage cost ((Stopford, 2009). Because of lower oil prices before 70 's, fuel cost was $13 \%$ of the total ship costs. However, a sharp increase in oil price during 80 's increased oil cost to $34 \%$ of the total ship costs. The jump in the oil price affected shipping industry and it started focusing on reducing fuel cost by change in the design of ship. Researchers also focused 
on how design can affect fuel savings. Another way by which shipping industry faced losses during 1973 was the lower demand from consumers. An increase in oil price resulted in inflation thereby reducing global demand for goods. A lower global demand coupled with increase in fuel cost for voyage put the shipping industry under pressure (Elveness \& Widiantoro, 2011). During 1970s' oil prices soared to new high and shipping industry faced its effects in the form of higher fuel costs. Initially, shipowners emphasized more on the design of the ship in order to lower fuel costs (Chou, Chou, Hsu, \& Lu, 2017; Notteboom \& Vernimmen, 2009; D. Ronen, 2011; Veenstra \& Ludema, 2006). Numerous researchers have tried to find alternative ways in which fuel costs can be minimized for ships (Abadie, Goicoechea, \& Galarraga, 2017; Bialystocki \& Konovessis, 2016; Psaraftis \& Kontovas, 2014).

With the global integration of markets, it has the spillovers from one commodity to another and from one industry to other became a major concern for industries. The relationship between oil and economy was first established by (Hamilton, 1983; Mork, 1989). Afterwards, numerous researchers have emphasized to investigate the spillovers from oil to industries also in order to reduce risk across markets and industries. Oil prices started appreciating after 2000 and crowned until 2008. With the financial crisis of 2008, oil prices suddenly dropped and gradually recovered after the financial crisis. This rise in price was halted in 2016 and started declining. This volatility in oil prices has benefited some of the industries, however oil dependent industries were seriously affected by the inflated oil prices.

Since tanker shipping industry is the main carrier of oil and it also using oil as input. The demand for the tanker shipping industry is derived demand since it depends on the oil demand also. Risk and returns associated with shipping industry are different from other industries (Drobetz, Schilling and Tegtmeier, 2010). Moreover, there is hardly any studies which investigate the impact of oil price returns' spillovers in the tanker market which is closely associated with the oil market.

Studying the relationship of oil with the firms closely connected to oil is important in generating accurate forecasts and building accurate asset pricing models. Therefore, I have selected two biggest tanker companies in the world and have investigated the time varying relationship between return spillovers from oil and tanker market. I employ VAR DCC-GARCH which is widely accepted among the research community to plot the time varying transmission of spillovers from one commodity to another. Apart from measuring time varying return transmission the main advantage of the method is that it provides meaning estimates of the parameters with less computational complications in comparison to other multivariate models. Results indicate a higher return spillover from oil to tanker companies specially post financial crisis period. Which can be useful for investors to diversify, hedge and better manage their risks in tanker shipping market. The remainder of the paper is organized as follows. In Section 2 we present the literature review followed by data and its diagnosis. The last sections contain results and conclusion for our study.

\section{Literature Review}

Fuel cost has been an important consideration for the shipping industry. Different methods have been devised to reduce the oil effect in order to generate higher returns. In order to reduce fuel cost numerous researchers have examined the relationship between ship's design and fuel consumption. While examining impact of fuel cost on the service configuration in container shipping Notteboom 
INTERNATIONAL JOURNAL OF ACADEMIC RESEARCH IN BUSINESS AND SOCIAL SCIENCES

Vol. 9, No. 1, Jan, 2019, E-ISSN: 2222-6990@ 2019 HRMARS

and Vernimmen (2009) showed that bunker fuel prices have a significant impact on the cost per TEU. The relationship between oil consumption and speed of a ship is exponential in nature (Veenstra and Ludema, 2006). Reduction in speed by $20 \%$ cuts fuel expenses by $50 \%$ (David Ronen, 1982). A higher speed burns more fuel and produces more carbon dioxide for which shipowners have to pay extra carbon tax (Chou et al., 2017).

Spillovers from oil market has been observed for various markets across countries. The effect of oil returns' transmission and volatility spillovers for US, Russia, Canada and Australia have been investigated by (Tsuji, 2018) by using VAR-DCC-MEGARCH. They saw unidirectional return transmission between oil futures and equities while bidirectional volatility spillovers were detected for volatility spillovers. North American stock markets were found more efficient than Russia and Australia and recommended hedging oil with equities. Another study about the China and U.S. highlights the time varying asymmetric relationship between oil and stock markets of both countries for a period 2007-2016 (Xu, Ma, Chen and Zhang, 2019). The study has made some interesting observations by considering bad and good volatility. They found an asymmetric spillover between the oil and stock markets and furthered that impact of bad volatility is more severe than good volatility. They were also of the view that investors are more pessimistic about the oil price than stock markets of both countries. By employing quantile regression analysis Hamdi, Aloui, Alqahtani, and Tiwari (2018) explored the relationship between oil price and GCC countries' stock markets. He showed that four sectors of the market were affected by the oil price while banking and insurance remained invulnerable during 10th, 25th and 75th quantiles. At the aggregate market index level transport and telecommunications were turned oblivious during the 75th and 90th quantiles. At the sectoral level of European markets, significant oil volatility spillovers effects has also been shown (Arouri, Jouini, \& Nguyen, 2012). Sadorsky (2012) by employing various multivariate GARCH models identified that correlation of oil with clean energy and technology companies is lower as compared to the correlation between the clean energy and technology sector .Identical to (Sadorsky, 2012), Maghyereh, Awartani, and Abdoh (2019) found significant bidirectional return and risk flowing from oil to the clean energy stocks. They found that these spillovers are stronger over the longer period of time.

Many researchers have tried to investigate the volatility transmission from oil to the food industry. Nazlioglu, Erdem, and Soytas (2013) examined the effect of volatility transmission from oil to agricultural commodities prices for wheat, sugar, soybean and corn. He examined the relationship by dividing his sample period into pre and post financial crisis. By employing causality in variance procedure, he observed no spillover before the financial crisis but a oil spillovers were observed for sugar in the post financial crisis period. His other analysis was based on impulse response function for which he observed the similar affects only after the financial crisis period. Kang, Mclver, and Yoon (2017) not only tested the volatility spillovers for the agricultural commodities he also included gold, oil and rice also. He employed DECO- GARCH and postulated a positive equi-correlation between the commodities future market returns which increased during the financial crisis. The main transmitters of return spillovers were gold and silver and interestingly oil and rest of the commodities were on the receiving end. He also observed higher return spillover effect during the financial crisis. In case of Chinese commodity market, the volatility connectedness of U.S. crude oil with agricultural commodity futures has also been shown by (Luo \& Ji, 2018). He posited a weak relationship between the two. He also observed leverage effect by segregating the volatility connectedness into positive 
and negative; negative volatility showed more connectedness than positive. Related to food market Fasanya \& Akinbowale (2019) found the similar results in case on Nigeria. Their results demonstrate trend and no burst in case of return spillovers, however both trend burst was found for volatility spillovers. In a weekly analysis agricultural commodity market Du, Yu, \& Hayes, (2011) found evidence of volatility spillover in corn and wheat markets.

Volatility spillovers from oil to industries has been observed in various industries other than oil dependent markets also. The volatility spillovers from oil are not limited to commodity market, currency market has also shown connectedness to the spills. Singh, Nishant, \& Kumar (2018) explored the dynamic and directional spillovers between oil and exchange rate for a period between 20072016 by employing Cholesky factor VAR variance decomposition along with network graph connected method. In case of directional spillovers, he found that oil is a net transmitter while currencies are the recipient of volatility spillovers. of the volatility spillovers. Euro and dollar were found to be the most sensitive to oil prices in his sample of nine currencies. Interesting disclosures have also been made about the commodity markets which are not dependent on oil as input also called non-energy commodity markets. Ji and Fan( 2012) observed the volatility spillovers between non-energy commodity market and oil prices and US dollar. The found a volatility spillovers effects of oil price in the market and also showed that volatility spillover effect appreciated after the financial crisis. On the contrary, they found that the volatility spillovers effect of dollar has weakened over the period. Research has shown that effects of volatility spillovers increased during and after the financial crisis (Kang et al., 2017; Nazlioglu et al., 2013).

Spillovers from oil and other commodities draw attention of researchers after the drastic effects of financial crisis across the globe. As the crisis intensified so did the spillovers started to increase ( $F$. $X$. Diebold and Yilmaz, 2012). He was also of the view that the main transmission of volatility spillovers started after the fall of Lehman Brothers. In his previous study, F. X. Diebold and Yilmaz (2009) he suggested a measure for return and volatility spillovers measurement and posited differing behaviour of return and volatility spillovers. He also showed that volatility spillovers have no trend but shows bursts while return spillovers show no bursts and have growing trend.

\section{Data}

The data for empirical analysis comprises daily prices of Frontline and Stolt Neilsen tanker shipping companies listed on Oslo Stock Exchange for the period 2000-2017. The main reason for selecting these companies is that these two companies are the largest in tanker markets in the world and their correlations with the oil can give important information about the overall tanker companies listed on Oslo stock market. All data has been collected from Thomson Reuters' DataStream and is in US dollars.

For oil price, we use daily WTI FOB spot prices obtained from Energy Information Administration (EIA) in US dollars. WTI is widely used in industry for hedging, futures and forwards (Aggarwal, Akhigbe, and Mohanty, 2012), and is one of the major benchmark for oil prices. We use spot prices instead of futures prices since most of the oil price shocks in the literature are studied based on the spot prices (Aggarwal et al., 2012). And also, future prices do not have a significant impact on stock market rather markets respond to spot prices (Huang, Masulis, \& Stoll, 1996). Daily stock returns were obtained using the following expression 
INTERNATIONAL JOURNAL OF ACADEMIC RESEARCH IN BUSINESS AND SOCIAL SCIENCES

Vol. 9, No. 1, Jan, 2019, E-ISSN: 2222-6990 @ 2019 HRMARS

$$
R_{i . t}=100 \times \ln \left(P R I C E_{i, t} / P R I C E_{i, t-1}\right)
$$

Where $P R I C E_{i, t}$ is the price of a firm i stock's price at time t while $P R I C E_{i, t-1}$ will be price of a firm $i$ for the previous period i.e. $t-1$.

\section{Descriptive Statistics}

Table 1 Descriptive Statistics

\begin{tabular}{|c|c|c|c|}
\hline & Frontline & Stolt Nielsen & Oil \\
\hline Mean & -0.02746 & -0.00725 & 0.018176 \\
\hline Median & 0 & 0 & 0 \\
\hline Maximum & 26.66056 & 17.57169 & 16.4137 \\
\hline Minimum & -56.4556 & -22.3803 & -17.0918 \\
\hline Std. Dev. & 3.940867 & 2.676259 & 2.408629 \\
\hline Skewness & -0.24957 & -0.1937 & -0.15893 \\
\hline Kurtosis & 15.84267 & 7.771089 & 7.34941 \\
\hline Jarque-Bera & 32307.09 & 4481.472 & 3719.683 \\
\hline Probability & $0.000 * * *$ & $0.000 * * *$ & $0.000 * * *$ \\
\hline Observations & 4694 & 4694 & 4694 \\
\hline
\end{tabular}

Table 1shows the summary statistics for Frontline, Stolt Nielsen and Oil prices' stock returns. It can be seen that higher kurtosis exist for all of the time series data. It is common occurrence in time series data to have higher kurtosis which shows that it contains heteroskedasticity and a GARCH type model is more suitable. The minimum values are for during the period of financial crisis. Shipping industry experienced huge losses during and after the financial crisis because of the lower global demand. On the other hand, it enjoyed supernormal profits for the period before the financial crisis. The change in earnings during these periods is reflected in standard deviation which can be termed as volatility for the time series. The average unconditional mean for the tanker companies is negative which is because of the lower returns in shipping industry owing to its cyclical nature and effect of financial crisis.

Table 2 Ljung Box and ARCH LM Test

\begin{tabular}{|c|l|l|l|l|l|l|}
\hline & Frontline & \multicolumn{3}{|l|}{ Stolt Nielsen } & Oil & \\
\hline Lags & Statistic & P Value & Statistic & P Value & Statistic & P value \\
\hline 5 & 10.0030 & $0.0751^{* * *}$ & 7.0750 & 0.2151 & 22.5250 & $0.0004 * * *$ \\
\hline 10 & 23.5950 & $0.0087^{* * *}$ & 14.0700 & 0.1698 & 29.5030 & $0.0010^{* * *}$ \\
\hline 15 & 30.5210 & $0.0101^{* * *}$ & 15.2190 & 0.4358 & 35.6100 & $0.0020^{* * *}$ \\
\hline 20 & 35.0360 & $0.0199 * * *$ & 19.6800 & 0.4781 & 38.8440 & $0.0069 * * *$ \\
\hline $\begin{array}{c}\text { ARCH LM } \\
(20)\end{array}$ & 240.4560 & $0.0000^{* * *}$ & 347.9140 & $0.0000^{* * *}$ & 664.9670 & $0.0000^{* * *}$ \\
\hline
\end{tabular}


INTERNATIONAL JOURNAL OF ACADEMIC RESEARCH IN BUSINESS AND SOCIAL SCIENCES

Vol. 9, No. 1, Jan, 2019, E-ISSN: 2222-6990 (C) 2019 HRMARS

The Ljung Box test and ARCH LM test shows that there is serial correlation in the time series data and ARCH LM suggests presence of conditional heteroscedasticity. So, a test from GARCH family would be an appropriate model for the time series data.

\section{Unit Root Test}

Although time series data for daily series usually does not pose problem of non-stationarity. However, it is important to check the series for unit root problem, since some of the data series selected for different time periods can pose non-stationarity. I employ ADF and PP test proposed by (Dickey \& Fuller, 1979; PHILLIPS \& PERRON, 1988). The unit root tests are performed for constant and constant and trend and lags are selected based on Schwarz

\section{Table 3 Unit Root Test}

\begin{tabular}{|l|l|l|l|l|l|l|}
\hline & \multicolumn{2}{l}{ Frontline } & \multicolumn{2}{l|}{ Stolt Nielsen } & Oil \\
\hline & ADF & PP & ADF & PP & ADF & PP \\
\hline Intercept & $-66.342^{* * *}$ & $-66.361^{* * *}$ & $-68.198^{* * *}$ & $-68.198^{* * *}$ & $-70.987^{* * *}$ & $-71.112^{* * *}$ \\
\hline Intercept and Trend & $-66.397^{* * *}$ & $-66.463^{* * *}$ & $-68.191^{* * *}$ & $-68.191^{* * *}$ & $-70.988^{* * *}$ & $-71.120^{* * *}$ \\
\hline
\end{tabular}

\section{Methodology}

Engle (1982) developed the autoregressive conditional heteroskedasticity (ARCH) model and was generalized by (Bollerslev, 1986). In order to model volatility of time series financial variables GARCH had been quite popular among researchers and is still considered efficient and effective among financial research community. Later, a class of multivariate GARCH models was developed which helps to study the conditional correlations among the assets in order to better look at the comovement. In this regard (R. Engle, 2002) proposed a model that allows to study time varying correlations among assets.

The model proposed can be written as

$$
\tau_{t}=\mu_{t}+a_{t}
$$

where $\tau_{t} \mathrm{n} \times 1$ vector of returns ( $\left.\log \right)$ at time $\mathrm{t} ; \mu_{t}$ is an $\mathrm{n} \times 1$ vector of expected value of $\tau_{t}$ while $a_{t}$ is $\mathrm{n} \times 1$ vector of mean-corrected returns at time $\mathrm{t}$ and $a_{t}=\tau_{t} \neq \mu_{t}$

$$
a_{t}=H_{t}^{\frac{1}{2}} z_{t}
$$

$z_{t}$ stands for $\mathrm{n} \times 1$ vector of $i$ id errors. The conditional covariance matrix $H_{t}$ in DCC-GARCH is written as

$$
H_{t}=D_{t} R_{t} D_{t}
$$

here $H_{t}$ is the conditional covariance matrix; $D_{t}$ is $\mathrm{n} \times \mathrm{n}$ diagonal matrix with conditional standard deviations of $a_{t}$ and takes the form 


$$
D_{t}=\left[\begin{array}{ccc}
h_{11 t}^{\frac{1}{2}} & \cdots & 0 \\
\vdots & \ddots & \vdots \\
0 & \cdots & h_{n n t}^{\frac{1}{2}}
\end{array}\right]
$$

From the univariate GARCH model where $h_{t}$ is time varying as can be seen

$h_{i t}$ in case of DCC GARCH is

$$
h_{t}=\alpha_{0}+\sum_{i=1}^{q} \alpha_{i} a_{t-1}^{2}+\sum_{j=1}^{p} \beta_{j} h_{t-1}
$$

$$
h_{i t}=\alpha_{i 0}+\sum_{q=1}^{Q_{i}} \alpha_{i q} a_{i, t-q}^{2}+\sum_{p=1}^{P_{i}} \beta_{i p} h_{i, t-q}
$$

$R_{t}$ from the Equation (3) is a conditional correlation matrix represented as

$$
R_{t}=\left[\begin{array}{ccccc}
1 & \rho_{12, t} & \rho_{13, t} & \cdots & \rho_{1 n, t} \\
\rho_{21, t} & 1 & \rho_{23, t} & \cdots & \rho_{2 n, t} \\
\rho_{31, t} & \rho_{32, t} & 1 & \ddots & \vdots \\
\vdots & \vdots & \ddots & 1 & \rho_{n-1, n, t} \\
\rho_{n 1, t} & \rho_{n 2, t} & \cdots & \rho_{n, n-1, t} & 1
\end{array}\right]
$$

From above it can be seen that DCC-GARCH allows for time varying correlations while considering conditional variances of stock returns or volatilities. Which is helpful for us to understand how over time different assets move together. In order to ensure the positive definiteness of $R_{t}$ it is modelled as

Where

$$
R_{t}=\dot{Q}_{o s, t}^{-1} Q_{o s, t} \dot{Q}_{o s, t}^{-1}
$$

$$
Q_{o s, t}=\left(1-\theta_{1}-\theta_{2}\right) \dot{Q}+\theta_{1} \xi_{t-1} \xi_{t-1}+\theta_{2} Q_{t-1}
$$

Here $Q_{o s, t}$ denotes the unconditional variance between $i$ and $j$ and follows GARCH. $\theta_{1}$ and $\theta_{2}$ are positive scalar parameters which satisfy $\theta_{1}+\theta_{2}<1$

\section{Results and Discussion}

This section shows the results obtained from VAR DCC- GARCH. First, we estimated the VAR for which the selection for the lag length criteria is presented in Table 4. The results for DCC GARCH are presented in Table 5 .

Table 4 Statistics for Selecting the lag

\begin{tabular}{|l|l|l|l|}
\hline & AICC & SBC/BIC & SBC/BIC \\
\hline & Selection & Lag & Selection \\
\hline $\mathbf{0}$ & 14.84427 & 0 & $14.8483975^{*}$ \\
\hline $\mathbf{1}$ & $14.8365731^{*}$ & 1 & 14.85309 \\
\hline $\mathbf{2}$ & 14.83696 & 2 & 14.86586 \\
\hline $\mathbf{3}$ & 14.83688 & 3 & 14.87816 \\
\hline $\mathbf{4}$ & 14.83781 & 4 & 14.89146 \\
\hline $\mathbf{5}$ & 14.83828 & 5 & 14.9043
\end{tabular}


INTERNATIONAL JOURNAL OF ACADEMIC RESEARCH IN BUSINESS AND SOCIAL SCIENCES Vol. 9, No. 1, Jan, 2019, E-ISSN: 2222-6990 @ 2019 HRMARS

\section{Table 5 DCC GARCH Parameters Estimates}

\begin{tabular}{|c|c|c|c|c|}
\hline & Coefficient & Std. Error & T-Stat & Significance \\
\hline \multicolumn{5}{|c|}{ Conditional Mean Equation } \\
\hline \multicolumn{5}{|l|}{ (Frontline) } \\
\hline Frontline (1) & 0.0178 & 0.0173 & 1.0268 & 0.3045 \\
\hline OIL (1) & 0.1022 & 0.0208 & 4.9041 & $0.0000 * * *$ \\
\hline Stolt Nielsen (1) & -0.0181 & 0.0187 & -0.9722 & 0.3310 \\
\hline Constant & -0.0188 & 0.0430 & -0.4368 & 0.6623 \\
\hline \multicolumn{5}{|l|}{ (OIL) } \\
\hline Frontline (1) & 0.0005 & 0.0069 & 0.0696 & 0.9445 \\
\hline OIL (1) & -0.0375 & 0.0154 & -2.4378 & $0.0148 * *$ \\
\hline Stolt Nielsen (1) & 0.0085 & 0.0107 & 0.7920 & 0.4284 \\
\hline Constant & 0.0505 & 0.0329 & 1.5350 & 0.1248 \\
\hline \multicolumn{5}{|l|}{ (Stolt Nielsen) } \\
\hline Frontline & 0.0278 & 0.0112 & 2.4728 & $0.0134^{* *}$ \\
\hline OIL (1) & 0.0802 & 0.0156 & 5.1286 & $0.0000 * * *$ \\
\hline Stolt Nielsen (1) & -0.0264 & 0.0174 & -1.5173 & 0.1292 \\
\hline Constant & 0.0135 & 0.0355 & 0.3798 & 0.7041 \\
\hline \multicolumn{5}{|c|}{ Conditional Variances } \\
\hline C (1) & 0.1112 & 0.0511 & 2.1762 & $0.0295^{* *}$ \\
\hline$C(2)$ & 0.0333 & 0.0150 & 2.2168 & $0.0266 * *$ \\
\hline$C(3)$ & 0.0321 & 0.0141 & 2.2812 & $0.0225^{* *}$ \\
\hline $\mathrm{A}(1,1)$ & 0.0527 & 0.0137 & 3.8364 & $0.0001 * * *$ \\
\hline$A(1,2)$ & 0.0123 & 0.0133 & 0.9299 & 0.3524 \\
\hline $\mathrm{A}(1,3)$ & 0.0015 & 0.0080 & 0.1904 & 0.8490 \\
\hline $\mathrm{A}(2,1)$ & 0.0004 & 0.0008 & 0.5181 & 0.6044 \\
\hline$A(2,2)$ & 0.0520 & 0.0162 & 3.2076 & $0.0013^{* * *}$ \\
\hline$A(2,3)$ & 0.0029 & 0.0045 & 0.6403 & 0.5220 \\
\hline $\mathrm{A}(3,1)$ & 0.0035 & 0.0015 & 2.3273 & $0.0200 * *$ \\
\hline$A(3,2)$ & 0.0057 & 0.0057 & 0.9898 & 0.3223 \\
\hline $\mathrm{A}(3,3)$ & 0.0188 & 0.0070 & 2.6753 & $0.0075^{* * *}$ \\
\hline $\mathrm{B}(1,1)$ & 0.9419 & 0.0157 & 60.0053 & $0.0000^{* * *}$ \\
\hline $\mathrm{B}(1,2)$ & -0.0066 & 0.0198 & -0.3323 & 0.7396 \\
\hline $\mathrm{B}(1,3)$ & -0.0068 & 0.0135 & -0.4999 & 0.6171 \\
\hline $\mathrm{B}(2,1)$ & -0.0011 & 0.0009 & -1.2625 & 0.2068 \\
\hline $\mathrm{B}(2,2)$ & 0.9369 & 0.0217 & 43.2280 & $0.0000 * * *$ \\
\hline $\mathrm{B}(2,3)$ & 0.0035 & 0.0093 & 0.3780 & 0.7054 \\
\hline $\mathrm{B}(3,1)$ & -0.0041 & 0.0016 & -2.6211 & $0.0088 * *$ \\
\hline $\mathrm{B}(3,2)$ & -0.0035 & 0.0083 & -0.4202 & 0.6744 \\
\hline $\mathrm{B}(3,3)$ & 0.9762 & 0.0105 & 93.2686 & $0.0000 * * *$ \\
\hline$\theta 1$ & 0.0067 & 0.0012 & 5.5305 & $0.0000 * * *$ \\
\hline Qn & n กחก? & ก กก17 & ז0כ กา1ก & ก กกกn*** \\
\hline
\end{tabular}


INTERNATIONAL JOURNAL OF ACADEMIC RESEARCH IN BUSINESS AND SOCIAL SCIENCES Vol. 9, No. 1, Jan, 2019, E-ISSN: 2222-6990 @ 2019 HRMARS

Table 6 Diagnostics Test (Ljung Box, Information Criteria, Loglikelihood)

\begin{tabular}{|l|l|l|l|l|l|l|}
\hline & Frontline & & Oil & \multicolumn{3}{|c|}{ Stolt Nielsen } \\
\hline $\mathrm{Q}(20) \mathrm{r}$ & 14.89864 & 0.78218 & 7.94323 & 0.99224 & 16.80111 & 0.66585 \\
\hline $\mathrm{Q}(20) \mathrm{r}^{\wedge} 2$ & 18.5261 & 0.55279 & 19.04527 & 0.51889 & 32.18135 & 0.0414 \\
\hline $\begin{array}{l}\text { Multivariate Q } \\
\text { Statistics }\end{array}$ & 3.523039 & 0.939917 & & & & \\
\hline Information Criteria & AIC & SBC & Hannan & (log) FPE & & \\
\hline & 14.221 & 14.269 & 14.238 & 14.221 & & \\
\hline Log Likelihood & -33263.4 & & & & & \\
\hline
\end{tabular}

The coefficients $\mathrm{A}(i, j)$ presented in Table 5 indicates $\mathrm{ARCH}$ effects and shows the return spillovers among variables as a result of own conditional volatility for short run persistence. The coefficients $B$ $(1,1), B(2,2)$ and $B(3,3)$ (GARCH terms) are all significant indicating that the impact of past innovations on the current conditional volatility is there for the longer periods also. Return spillovers among Frontline and Stolt Nielsen are present for the short run as indicated by $A(3,1)$. The same relationship can be seen for the longer period also. However, as seen from the coefficient values the impact is positive and weak in the short run but it turns out to be negative in the longer run and is stronger than the short run. From the mean equation model the relationship between Stolt Nielsen and oil is significant and positive. A same positive relationship also exists for Frontline and oil also. From the DCC GARCH term $\theta 1$, can be seen the presence of movement as a result of past innovations can be seen. $\theta 2$ shows the existence of strong correlation between oil and tanker companies of the Oslo Stock Market. The estimated coefficients $\theta 1$ and $\theta 2$ are each significant at $1 \%$ significance level and are positive. The sum of these two parameters is also less than 1 which indicates that dynamic conditional correlations are mean reverting.

From the Figure 1 we can see some periods of greater correlations among all the variables. Which is soon after the period of financial crisis. The correlation of Frontline with oil remain consistent and at a lower level for much of the period before the financial crisis. Post financial crisis it increased from 0.2 to 0.4 and slowly decreased until 2011. Another jump after 2011 is the period when oil prices were increasing while tanker market reached its lowest levels. Even the Baltic Tanker Indices were at the lowest points of history. The relationship seems to dip from 2011 onwards. However, it became negative at the start of 2014 but within a year it again become positive. The correlation after 2016 is increasing and an average correlation is above the correlation before the financial crisis. The correlation among both the tanker companies selected in our analysis is greater than with the oil for both the companies. Return spillovers among the companies increased to a larger extent during and after the financial crisis period. However, it has decreased since after 2012. There exists lower correlation between oil and Stolt Nielsen and it spiked during the financial crisis period. The return spillover effects of oil are greater in case of Stolt Nielsen, however it never turned out to be negative during our whole sample period. After 2014, for some time the time varying relationship of Frontline 
INTERNATIONAL JOURNAL OF ACADEMIC RESEARCH IN BUSINESS AND SOCIAL SCIENCES Vol. 9, No. 1, Jan, 2019, E-ISSN: 2222-6990 @ 2019 HRMARS

with oil became negative but even during that period the relationship remained positive for Stolt Nielsen.

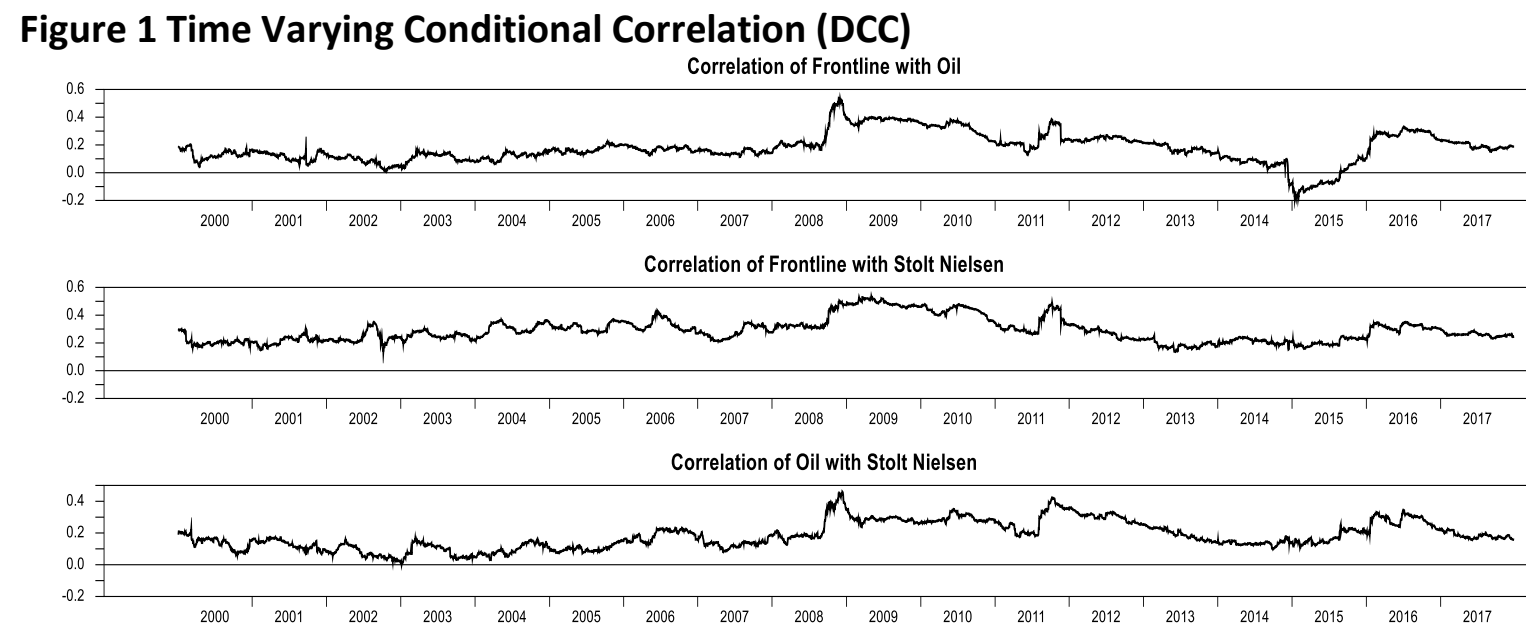

Time-varying conditional correlations from DCC model

\section{Conclusion}

We investigated the time varying return spillovers from oil to the world biggest tanker shipping companies i.e. Frontline and Stolt Nielsen. We applied VAR DCC-GARCH, which is widely accepted among research community to examine the existence of time varying conditional relationships among assets. We observe a weak time varying conditional correlation among the returns of oil, Frontline and Stolt Nielsen. However, the relationship is pronounced after the financial crisis of 2008. Which confirms the hypothesis of F. X. Diebold and Yilmaz (2012) that spillovers effects were stronger and more pronounced among markets after the financial crisis of 2008 . We also observe that the dynamic conditional correlations among Frontline and Stolt Nielsen is higher than the correlations of the two companies with the oil. This directs that the tanker companies have more in common than their relationship with the oil. Future research should be aimed to investigate the dynamic volatility spillovers effects of oil for the whole tanker market.

The results are of great interest for portfolio manager, investors and policymakers. The correlations among the oil and tanker market are useful for hedging and portfolio diversification. Our results also suggest that investors should not only hedge themselves during the period of financial turmoil, but they should likewise be watchful in planning for the periods following the financial stress period. The results of correlations will also aid the investors whose portfolio includes assets from tanker shipping companies while determining optimal portfolio.

\section{References}

Abadie, L. M., Goicoechea, N., \& Galarraga, I. (2017). Adapting the shipping sector to stricter emissions regulations: Fuel switching or installing a scrubber? Transportation Research Part D, 57, 237-250

Aggarwal, R., Akhigbe, A., \& Mohanty, S. K. (2012). Oil price shocks and transportation firm asset prices. Energy Economics, 34(5), 1370-1379

Arouri, M. E. H., Jouini, J., \& Nguyen, D. K. (2012). On the impacts of oil price fluctuations on 
INTERNATIONAL JOURNAL OF ACADEMIC RESEARCH IN BUSINESS AND SOCIAL SCIENCES

Vol. 9, No. 1, Jan, 2019, E-ISSN: 2222-6990 @ 2019 HRMARS

European equity markets: Volatility spillover and hedging effectiveness. Energy Economics, 34(2), 611-617

Bialystocki, N., \& Konovessis, D. (2016). On the estimation of ship's fuel consumption and speed curve: A statistical approach. Journal of Ocean Engineering and Science, 1(2), 157-166.

Bollerslev, T. (1986). Generalized autoregressive conditional heteroskedasticity. Journal of Econometrics, 31(3), 307-327

Chou, M.-T., Chou, T.-Y., Hsu, Y.-R., \& Lu, C.-P. (2017). Fuel Consumption Ratio Analysis for Transiting from Various Ports and Harbours in Asia through the Northern Sea Route. Journal of Navigation, 70(04), 859-869

Dickey, D. A., \& Fuller, W. A. (1979). Distribution of the Estimators for Autoregressive Time Series with a Unit Root. Journal of the American Statistical Association.

Diebold, F. X. K. Y. (2008). MEASURING FINANCIAL ASSET RETURN AND VOLATILITY SPILLOVERS, WITH APPLICATION TO GLOBAL EQUITY MARKETS Francis, 119(08), 158-171.

Diebold, F. X., \& Yilmaz, K. (2009). Measuring Financial Asset Return and Volatility Spillovers, with Application to Global Equity Markets. The Economic Journal, 119(534), 158-171.

Diebold, F. X., \& Yilmaz, K. (2012). Better to give than to receive: Predictive directional measurement of volatility spillovers. International Journal of Forecasting, 28(1), 57-66.

Drobetz, W., Schilling, D., \& Tegtmeier, L. (2010). Common risk factors in the returns of shipping stocks. Maritime Policy and Management, 37(2), 93-120.

Du, X., Yu, C. L., \& Hayes, D. J. (2011). Speculation and volatility spillover in the crude oil and agricultural commodity markets: A Bayesian analysis. Energy Economics, 33(3), 497-503.

Elveness, V. B., \& Widiantoro, D. M. (2011). Managing Risk in Financial Market in Shipping Industry. SSRN Electronic Journal

Engle, R. (2002). DYNAMIC CONDITIONAL CORRELATION - A SIMPLE CLASS OF MULTIVARIATE GARCH MODELS July 1999 Revised Jan 2002 Forthcoming Journal of Business and Economic Statistics 2002. Journal of Business, (July 1999), 1-34.

Engle, R. F. (1982). Autoregressive Conditional Heteroscedasticity with Estimates of the Variance of United Kingdom Inflation. Econometrica, 50(4), 987

Fasanya, I., \& Akinbowale, S. (2019). Modelling the return and volatility spillovers of crude oil and food prices in Nigeria. Energy, 169, 186-205

Hamdi, B., Aloui, M., Alqahtani, F., \& Tiwari, A. (2018). Relationship between the oil price volatility and sectoral stock markets in oil-exporting economies: Evidence from wavelet nonlinear denoised based quantile and Granger-causality analysis. Energy Economics,

Hamilton, J. D. (1983). Oil and the Macroeconomy since World War II. Journal of Political Economy, 91(2), 228-248

Huang, R. D., Masulis, R. W., \& Stoll, H. R. (1996). Energy shocks and financial markets. Journal of Futures Markets, 16(1), 1-27.

Ji, Q., \& Fan, Y. (2012). How does oil price volatility affect non-energy commodity markets? Applied Energy, 89(1), 273-280

Kang, S. H., Mclver, R., \& Yoon, S.-M. (2017). Dynamic spillover effects among crude oil, precious metal, and agricultural commodity futures markets. Energy Economics, 62, 19-32.

Luo, J., \& Ji, Q. (2018). High-frequency volatility connectedness between the US crude oil market 
INTERNATIONAL JOURNAL OF ACADEMIC RESEARCH IN BUSINESS AND SOCIAL SCIENCES

Vol. 9, No. 1, Jan, 2019, E-ISSN: 2222-6990 (C) 2019 HRMARS

and China's agricultural commodity markets. Energy Economics, 76, 424-438.

Maghyereh, A. I., Awartani, B., \& Abdoh, H. (2019). The co-movement between oil and clean energy stocks: A wavelet-based analysis of horizon associations. Energy, 169(2019), 895-913

Mork, K. A. (1989). Oil and the Macroeconomy When Prices Go Up and Down : An Extension of Hamilton's Results Author ( $s$ ): Knut Anton Mork Source : Journal of Political Economy, Vol . 97 , No . 3 ( Jun ., 1989 ), pp . 740-744, 97(3), 740-744.

Nazlioglu, S., Erdem, C., \& Soytas, U. (2013). Volatility spillover between oil and agricultural commodity markets. Energy Economics, 36, 658-665.

Notteboom, T. E., \& Vernimmen, B. (2009). The effect of high fuel costs on liner service configuration in container shipping. Journal of Transport Geography, 17(5), 325-337.

PHILLIPS, P. C. B., \& PERRON, P. (1988). Testing for a unit root in time series regression. Biometrika, 75(2), 335-346

Psaraftis, H. N., \& Kontovas, C. A. (2014). Ship speed optimization: Concepts, models and combined speed-routing scenarios. Transportation Research Part C: Emerging Technologies, 44, 52-69.

Ronen, D. (1982). The effect of oil price on the optimal speed of ships. Journal of the Operational Research Society, 33(11), 1035-1040

Ronen, D. (2011). The effect of oil price on containership speed and fleet size. Journal of the Operational Research Society, 62(1), 211-216

Sadorsky, P. (2012). Correlations and volatility spillovers between oil prices and the stock prices of clean energy and technology companies. Energy Economics, 34(1), 248-255.

Singh, V. K., Nishant, S., \& Kumar, P. (2018). Dynamic and directional network connectedness of crude oil and currencies: Evidence from implied volatility. Energy Economics, 76, 48-63.

Stopford, M. (2009). Maritime Economics 3ed. Routledge

Tsuji, C. (2018). New DCC analyses of return transmission, volatility spillovers, and optimal hedging among oil futures and oil equities in oil-producing countries. Applied Energy, 229(July), 12021217

Veenstra, A. W., \& Ludema, M. W. (2006). The relationship between design and economic performance of ships. Maritime Policy and Management, 33(2), 159-171.

Xu, W., Ma, F., Chen, W., \& Zhang, B. (2019). Asymmetric volatility spillovers between oil and stock markets: Evidence from China and the United States. Energy Economics, 80, 310-320. 